九州大学学術情報リポジトリ

Kyushu University Institutional Repository

\title{
Assessment of Greenhouse Gases Emission from Integrated Solid Waste Management in Semarang City, Central Java, Indonesia
}

Syafrudin

Department of Environmental Engineering, Faculty of Engineering, Diponegoro University

Mochamad Arief Budihardjo

Department of Environmental Engineering, Faculty of Engineering, Diponegoro University

Nany Yuliastuti

Department of Urban and Regional Planning, Faculty of Engineering, Diponegoro University

Bimastyaj i Surya Ramadan

Department of Environmental Engineering, Faculty of Engineering, Diponegoro University

https://doi.org/10.5109/4372257

出版情報: Evergreen. 8 (1)，pp. 23-35，2021-03. Transdisciplinary Research and Education Center for Green Technologies, Kyushu University バージョン :

権利関係 : 


\title{
Assessment of Greenhouse Gases Emission from Integrated Solid Waste Management in Semarang City, Central Java, Indonesia
}

\author{
Syafrudin ${ }^{1}$, Mochamad Arief Budihardjo ${ }^{1}$, Nany Yuliastuti ${ }^{2}$, Bimastyaji Surya \\ Ramadan ${ }^{1, *}$ \\ ${ }^{1}$ Department of Environmental Engineering, Faculty of Engineering, Diponegoro University, \\ Semarang - 50277, Indonesia \\ ${ }^{2}$ Department of Urban and Regional Planning, Faculty of Engineering, Diponegoro University, \\ Semarang - 50277, Indonesia
}

*Author to whom correspondence should be addressed: E-mail: bimastyaji@live.undip.ac.id

(Received October 7, 2020; Revised January 13, 2021; accepted February 15, 2021).

\begin{abstract}
This study has purposes calculating GHG emissions using the IPCC calculation methods (default) to estimate the potential for GHG emissions in the reduce, reuse, and recycle (3R) activities in integrated temporary waste storages (ITWSs), waste transportation, and the Jatibarang landfill. The results of this study indicate that the landfill activity has the greatest value of GHG emission potential compared with other activities. Optimization of $3 \mathrm{R}$ activities at the landfill site is also considered capable of reducing the GHG emissions of the existing waste by up to $75 \%$ without composting.
\end{abstract}

Keywords: integrated temporary waste disposal, IPCC methods, Jatibarang Landfill, LandGEM v3.02, waste management, 3R concepts

\section{Introduction}

Organic waste dumping can result in the release of tons of methane $\left(\mathrm{CH}_{4}\right)$. Nevertheless, waste composting contributes to $\mathrm{CO}_{2}$ and $\mathrm{N}_{2} \mathrm{O}$ emissions in smaller amounts compared with the anaerobic process in landfills ${ }^{1}$. Methane gas is produced from the breakdown of organic materials present at the final disposal site, which can reach around $50 \%-60 \%$ of the total gas produced ${ }^{2}$. This gas has a greater global warming potential (GWP) than carbon dioxide; its GWP is about 28 times that caused by $\mathrm{CO}_{2}$ in 100 years ${ }^{3}$. Methane is produced by various emitters on earth, both by natural and anthropogenic sources. As with $\mathrm{CH}_{4}, \mathrm{~N}_{2} \mathrm{O}$ comes from natural and anthropogenic sources. The main anthropogenic sources are agriculture, the use of animal fertilizers, waste management, the use of fuel in mobile and stationary sources, adipic acid production process, and nitric acid production. Nitrous oxide is also produced naturally from various biological sources in soil and water, especially from microbial activities in wet tropical forests, where $\mathrm{N}_{2} \mathrm{O}$ is formed in the aerobic composting process ${ }^{4)}$. The Kyoto protocol convention states that the concentration of greenhouse gases (GHGs) including $\mathrm{N}_{2} \mathrm{O}$ in all developed countries must be reversed to the conditions in 1990 , or approximately $5 \%$ of the current emissions ${ }^{5), 6)}$. In addition to $\mathrm{N}_{2} \mathrm{O}$ and $\mathrm{CH}_{4}$, carbon dioxide pollutant also mainly comes from anthropogenic sources, in forms such as the off-gas combustion of fossil fuels as a power source $(70 \%-90 \%)$ and land use conversion $(10 \%-30 \%)^{7}$. In addition, $\mathrm{CO}_{2}$ gas also comes from natural sources such as volcanic gas, combustion of organic materials, and aerobic organisms' respiration process. Carbon dioxide emissions resulting from human activities (anthropogenic) are relatively higher in concentration so that they disrupt the atmosphere equilibrium system and can ultimately damage the environment and human wellbeing ${ }^{8}$.

Waste is a massive urban problem, considering its complex impacts, which include aesthetics, health, economic, and environmental losses that lead to natural disasters ${ }^{9}$. The amount of GHG emissions released into the atmosphere is estimated to increase every year. For example, in China, this GHG emission increased from $17 \%$ in 1979 to $69.5 \%$ in $2013^{10)}$. This means that the GHG emissions in the atmosphere increase by $1.5 \%$ annually, and if this increase continues to be ignored, the greenhouse effect of landfilling activities will be greater in the future ${ }^{11)}$. In terms of policy, Indonesian government through law no. 18/2008 has stated that MSW must be managed and handled properly, and activities for waste reduction and recycling, separation, transportation, 
collection, and processing should be carried out ${ }^{12)}$. Differences in municipal waste management can result in different GHG emission potentials because the emission depends on the landfilling method and the integration of the principles of waste reduction at the source, recycling, and reuse of valuable waste. The waste sector is estimated to contribute as much as $7 \%$ of the total methane emissions worldwide ${ }^{13)}$. Without proper handling of waste, these emissions will continue to increase along with population growth and human activities.

The Semarang City government has tried to reduce waste from the source through the concept of reduce, reuse, recycle by providing the Jatibarang landfill to accommodate residues and constructing a waste bank as a form of household-based waste management in the community $^{2}$. However, these efforts have not been able to overcome the waste problem in the city. The government plays a role in the provision of communal waste containers, transportation, collection, composting, and final processing of waste. To date, no study has tried to comprehensively evaluate these activities for GHG emissions. By knowing the contribution of each activity to GHG emissions, the potential for emission reduction from the waste sector can be determined, especially for Semarang City waste management.

This study aims to analyze the existing conditions of waste management in the city of Semarang from the formal sector and their impact on climate change. In-depth interviews were conducted to all formal stakeholders in the city to obtain an inventory of activities that are in accordance with the conditions on ground. The IPCC 2006 guidelines default method and Landfill Gas Emissions Model (LandGEM) are some of the methodologies of estimating the GHG emissions amount from solid waste activities ${ }^{5), 14)}$. Among these two models and methods, the IPCC 2006 guidelines default method is often used at the national level in various countries because of its ease and reliability in estimating the amount of methane $\left(\mathrm{CH}_{4}\right)$, carbon dioxide $\left(\mathrm{CO}_{2}\right)$, and nitrous oxide $\left(\mathrm{N}_{2} \mathrm{O}\right)$ released from various activities, including industrial activities, transportation, waste, agriculture and land use changes, and energy-generation activities ${ }^{15}$. The instructions contained in the 2006 IPCC have been internationally recognized to provide reports on the equivalent level of carbon dioxide emissions released from various activities, especially waste management at the city, provincial, and national levels ${ }^{6}$. In the present study, the IPCC default method is used to estimate GHGs production resulting from the activities of waste transfer landfills and composting at the landfill in the inventory year. LandGEM v.3.02 is also used to estimate the generation of methane gas that can be recovered as landfill gas (LFG) so that the methane contained in the closed landfill can be recovered and not just wasted through flares ${ }^{15)}$. This research can be used as a comprehensive reference to fill the gaps in the calculation of GHG emissions from the waste sector, especially in developing countries such as Indonesia. This research may be used as a potential tools for policy makers to make appropriate mitigation actions related to the reduction of emission from waste sector.

\section{Methods}

\subsection{Data Collection}

The profile of waste management in the city of Semarang is taken from the Office of the Environment, Semarang City. The profile is used as a reference to carry out an inventory of activities, both at integrated temporary waste storages (ITWSs), waste transportation, and the Jatibarang landfill. A survey census of 22 ITWSs in Semarang City was conducted based on available data (location addresses). In-depth interviews were conducted with the managers of the ITWSs and the Jatibarang landfill to learn the details of the activities at each study site. The fuel oil used for transportation is converted into GHG emission potential by the emission factor of each fuel type. Fig. 1 shows the scope of this study, while details on the interview questions and collected data can be seen in Table 1 .

Table 1. Interview Questions for Activity Inventory at ITWS and Landfill Sites

\begin{tabular}{|c|c|c|}
\hline Sampling Sites & Component & Sub Component \\
\hline \multirow{14}{*}{$\begin{array}{l}\text { Integrated } \\
\text { Temporary Waste } \\
\text { Storages }\end{array}$} & \multirow[t]{6}{*}{ Manager identity ITWS } & ITWS name and manager \\
\hline & & Age \\
\hline & & Location address and coordinates \\
\hline & & Service area \\
\hline & & Number of household heads served \\
\hline & & Operating time and capacity \\
\hline & \multirow[t]{3}{*}{ Waste management } & Waste management activities \\
\hline & & Implementation of composting \\
\hline & & Transportation of waste to landfill \\
\hline & \multirow[t]{3}{*}{ Fuel usage } & Fuel consumption for plastic counting \\
\hline & & Fuel consumption for leaf chopper \\
\hline & & Other tools such as motor trash and fuel consumption \\
\hline & \multirow{2}{*}{$\begin{array}{l}\text { Electricity use for offices and } \\
\text { other activities }\end{array}$} & ITWS total power \\
\hline & & Electricity usage fee per month \\
\hline
\end{tabular}




\begin{tabular}{|c|c|c|}
\hline Sampling Sites & Component & Sub Component \\
\hline Waste Transportation & $\begin{array}{l}\text { The activity of transporting } \\
\text { waste to landfills }\end{array}$ & The type of fuel used and fuel requirements per day \\
\hline \multirow[t]{9}{*}{ Landfill Site } & \multirow{4}{*}{$\begin{array}{l}\text { Waste management activities } \\
\text { in landfills }\end{array}$} & Waste generation data entered per month \\
\hline & & Vehicles/heavy equipment operating in landfills \\
\hline & & $\begin{array}{l}\text { Total appliances, total electric power, and operating } \\
\text { hours of equipment at the landfill site }\end{array}$ \\
\hline & & Domestic wastewater \\
\hline & $\begin{array}{l}\text { Waste management activities } \\
\text { in the composting plant }\end{array}$ & Waste generation is processed into compost \\
\hline & \multirow[t]{4}{*}{ Scavenger activity } & $\begin{array}{l}\text { Respondent's identity, including name, age, gender, } \\
\text { and address }\end{array}$ \\
\hline & & Recycled waste generation \\
\hline & & Waste composition \\
\hline & & Monthly scavenger turnover \\
\hline
\end{tabular}

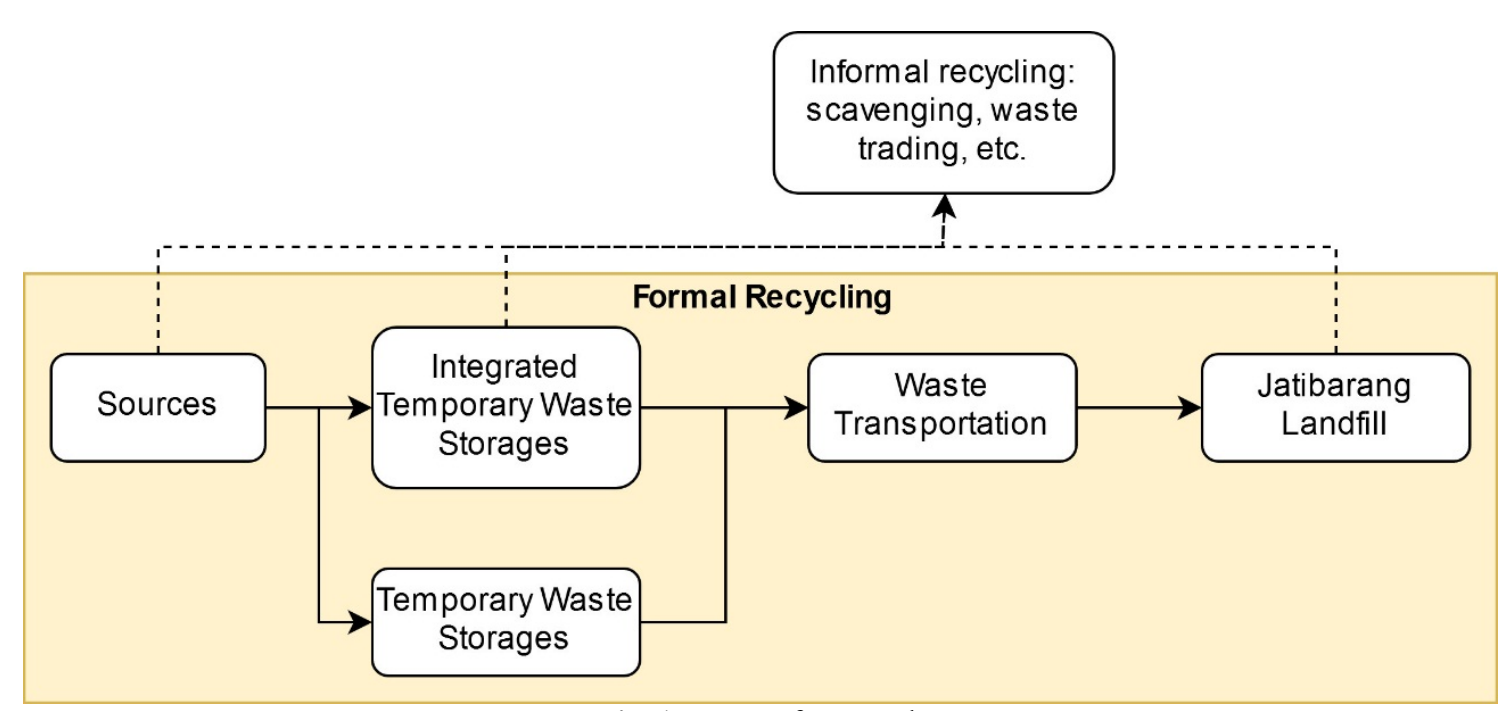

Fig. 1: Scope of Research

\subsection{Greenhouse Gases Inventory (IPCC Methods)}

The default IPCC 2006 method (Tier 1) in this study is used to estimate the GHGs generated in the ITWS, through waste transportation, and in the Jatibarang landfill. The amount of GHGs generated due to landfill activities is calculated theoretically based on the equation of GHG production, equation (1). The default method can be used when historical data on the waste quantity and composition are not available so the estimation of GHGs is based on the hypothesis that all gases are released directly into the environment and does not consider the time of the degradation process.

$$
\mathrm{CH}_{4} \text { emission }(\operatorname{ton} / \mathrm{y})=\left(\mathrm{MSW}_{T} \times \mathrm{MSW}_{f} \times \mathrm{DOC} \times \mathrm{DOC}_{F} \times \mathrm{F} \times \frac{16}{12}-R\right) \times(1-\mathrm{OX})
$$

where $\mathrm{MSW}_{T}$ is the total waste generation in landfill (ton/y), $\mathrm{MSW}_{f}$ is the fraction of accumulated waste $(100 \%), \mathrm{MCF}$ is the methane correction factor (0.4), DOC is the degradable organic carbon $\left(\mathrm{kg} \mathrm{C} / \mathrm{kg}\right.$ waste), $\mathrm{DOC}_{F}$ is the fraction of DOC $(0.5), \mathrm{F}$ is fraction by volume of $\mathrm{CH}_{4}$ in landfill (0.5), $\mathrm{OX}$ is oxidation factor (0.1), $\mathrm{R}$ is the recovered $\mathrm{CH}_{4}$ (ton/year), and $\frac{16}{12}$ is conversion from $\mathrm{C}$ to $\mathrm{CH}_{4}$. Although this method is recognized to be capable of estimating actual emissions, the actual methane produced does not always have a value close to that obtained from the calculation model. Methane production always depends on the amount and composition of waste in landfills ${ }^{16)}$.
In addition to landfill activities, in practice, most wastes in Indonesia are openly burned. Open burning can release $\mathrm{CO}_{2}, \mathrm{~N}_{2} \mathrm{O}$, and $\mathrm{CH}_{4}$ directly into the atmosphere. Even so, for the same amount of organic waste, the emissions from waste burning are considered smaller than those from landfills. In this study, it is assumed that no waste is subjected to open burning, and thus, the calculation of emissions from open burning in Indonesia is ignored. Waste sorting and composting activities are also part of the waste management $3 R$ (reduce, reuse, recycle) principle. These activities involve sorting waste between inorganic and organic matter and then composting the organic fraction in a facility. The inorganic waste is 
recovered and reused to obtain the remaining economic value of the waste. In the Jatibarang landfill and ITWSs, inorganic waste is taken by scavengers and sold back to the stalls. This can help reduce the amount of waste in landfills. The biological composting process causes the release of methane emissions, which can be estimated through formula (2).

$$
\mathrm{CH}_{4} \text { emission }=\sum(\mathrm{Mi} \times \mathrm{Efi}) 10^{-3}-\mathrm{R}
$$

where Mi is the mass of composted garbage $(\mathrm{Gg} / \mathrm{y})$, Efi is the emission factor in the composting process $\left(\mathrm{g} \mathrm{CH}_{4} / \mathrm{kg}\right)$, and $\mathrm{R}$ is recovered emissions $\mathrm{CH}_{4}\left(\mathrm{Gg} \mathrm{CH}_{4}\right)$.

Furthermore, enumeration activities, transportation, and office activities also directly or indirectly affect the amount of emissions entering the environment. Fuel consumption produces $\mathrm{CO}_{2}, \mathrm{CH}_{4}$, and $\mathrm{N}_{2} \mathrm{O}$ emissions, which are assessed based on the engine type. Motor vehicles that use gasoline as fuel have emission factors of $69,300 \mathrm{~kg} / \mathrm{TJ} \mathrm{CO}_{2}, 3.0 \mathrm{~kg} / \mathrm{TJ} \mathrm{CH}_{4}$, and $0.6 \mathrm{~kg} / \mathrm{TJ} \mathrm{N}_{2} \mathrm{O}$. Diesel engines have a greater emission factor value: $74,100 \mathrm{~kg} / \mathrm{TJ}$ for $\mathrm{CO}_{2}$ and $0.6 \mathrm{~kg} / \mathrm{TJ}$ for $\mathrm{CH}_{4}$ and $\mathrm{N}_{2} \mathrm{O}$. The emissions released from these systems are calculated using formula (3).

Emission $=\mathrm{EC} \times \mathrm{EF}$

where the emission value is the energy system emission (kg), EC is the energy consumption, and EF is the emission factor for certain technology types (based on fuel used) for certain pollutants. In this study, the value of $\mathrm{CO}_{2}$ emissions is calculated using equation (4).

$$
\mathrm{CO}_{2} \text { emission }=\mathrm{EC} \times \mathrm{EF} \times \mathrm{NCV}
$$

where $\mathrm{CO}_{2}$ emission is the total $\mathrm{CO}_{2}$ emissions per year (kg/year), EC is energy consumption, $\mathrm{EF}$ is the fuel $\mathrm{CO}_{2}$ emission factor $(\mathrm{kg} / \mathrm{TJ})$, and $\mathrm{NCV}$ is the net calorific volume (energy content) per unit mass or fuel volume (TJ/ton fuel). The NCV is $43 \mathrm{TJ} / \mathrm{Gg}$ and diesel density is $0,832 \mathrm{~kg} / \mathrm{L}$. Energy consumption can be calculated by multiplying the electricity consumption value, amount of fuel, and the heating value of the fuel used. Electricity consumption is calculated based on the power of each appliance multiplied by the time of use (hours). In this study, the $\mathrm{CO}_{2} \mathrm{EF}$ for electricity consumption was set as 586.32 ton $\mathrm{CO}_{2} / \mathrm{GWh}$, equivalent to 0.000586 ton $\mathrm{CO}_{2} / \mathrm{KWh}$. The value of emissions from electricity use is calculated using equation (5).

$$
\mathrm{EF}=\mathrm{SFC} \times \mathrm{NCV} \times \mathrm{CEF} \times \mathrm{Oxid} \times 44 / 12
$$

where $\mathrm{EF}$ is the $\mathrm{CO}_{2}$ emission factor, SFC denotes the specific fuel consumption, $\mathrm{NCV} /$ is the net calorific volume (energy content) per unit mass or volume of fuel (TJ/ton fuel), CEF denotes the carbon emission factor $\left(\mathrm{TCO}_{2} / \mathrm{TJ}\right)$, and Oxid is the oxidation factor.
The amount of $\mathrm{CH}_{4}$ emissions from domestic wastewater is determined by considering the EFs in wastewater management. The EFs are obtained from the function of the maximum potential production of $\mathrm{CH}_{4}\left(\mathrm{~B}_{\mathrm{o}}\right)$ and methane correction factors (MCF), which are different in each type of wastewater management. The EFs for each wastewater management are obtained using equation (6), assuming methane $\left(\mathrm{B}_{\mathrm{o}}\right)$ production capacity is $0.6 \mathrm{~kg} \mathrm{CH}_{4} / \mathrm{kg}$ biological oxygen demand (BOD), the $\mathrm{MCF}$ for septic tanks is 0.5 for open channels and 0.5 for non-flowing channels.

$$
\mathrm{EF}_{\mathrm{j}}=\mathrm{B}_{\mathrm{o}} \times \mathrm{MCF}
$$

Other factors that influence $\mathrm{CH}_{4}$ emissions are the population fraction (U) and the level of the wastewater treatment system usage $(\mathrm{T})$. The value of $\mathrm{T}$ is obtained from the total discharge of wastewater treated through the management systems, such as septic tanks, and the untreated wastewater. The septic tank usage rate is $75 \%$ and without processing $25 \%$. After analyzing the data in the form of the total organic content in wastewater (TOW), wastewater management EF, population fractions contained in the Jatibarang landfill (U), and the level of wastewater treatment systems usage applied in the Jatibarang landfill (T), the amount of $\mathrm{CH}_{4}$ emissions generated in one year due to wastewater management in the Jatibarang landfill can be calculated using equation (7).

$$
\mathrm{CH}_{4} \text { Emission }=\mathrm{U}_{\mathrm{i}} \times \mathrm{T}_{\mathrm{j}} \times \mathrm{EF} \times \mathrm{TOW}
$$

where $\mathrm{CH}_{4}$ Emission is the $\mathrm{CH}_{4}$ emissions in one year $\left(\mathrm{TCH}_{4} /\right.$ year), TOW is the total organic load in one year (TBOD/year), $\mathrm{Ui}$ is the population fraction, $\mathrm{T}_{\mathrm{i}, \mathrm{j}}$ is the fraction of waste treatment system usage, $I$ is the population group, $\mathrm{j}$ is each type of waste treatment, and $\mathrm{EF}_{\mathrm{j}}$ is the emission factor $\left(\mathrm{TCH}_{4} / \mathrm{TBOD}\right)$. On the other hand, domestic wastewater also has the potential to produce $\mathrm{N}_{2} \mathrm{O}$ from the anaerobic process of overhauling organic compounds, where the amount of $\mathrm{N}_{2} \mathrm{O}$ produced is calculated using equation (8).

$$
\mathrm{N}_{2} \mathrm{O} \text { Emission }=\mathrm{N}_{\text {effluent }} \times \mathrm{EF}_{\text {effluent }} \times \frac{44}{28}
$$

where $\mathrm{N}_{2} \mathrm{O}$ Emission is the potential $\mathrm{N}_{2} \mathrm{O}$ emissions in one year $\left(\mathrm{TN}_{2} \mathrm{O}\right.$ /year), $\mathrm{N}_{\text {effluent }}$ is nitrogen in waste discharged into the aquatic environment (ton $\mathrm{N} /$ year), and $\mathrm{EF}_{\text {effluent }}$ is the emission factor for $\mathrm{N}_{2} \mathrm{O}$ wastewater (ton $\mathrm{N}_{2} \mathrm{O}-\mathrm{N} /$ ton N).

\subsection{LandGEM Methods}

The LandGEM method is used to predict the amount of methane/LFG produced from landfills. However, this calculation method requires the waste generation data from the beginning year of the landfill usage to the closing year. In this study, data on waste generation at the beginning year of the landfill usage is obtained by 
multiplying the assumed population in the considered year by the factor of waste generation per capita of 0.4 $\mathrm{kg} /$ person/day. The methane produced from a pile of landfill waste is calculated using equation (9).

$$
Q_{\text {Metana }}=\sum_{i=1}^{n} \sum_{j=0.1}^{1} k L_{0}\left(\frac{M_{i}}{10}\right) e^{-k t_{i j}}
$$

where $Q_{\text {Metana }}$ represents the estimated methane gas production per year, calculated in $\mathrm{m}^{3} /$ year; $i$ is the additional year; $n$ is the number of predicted years; $j$ is 0.1 additional years; $\mathrm{k}$ is the constant formation of methane gas (1/year); $\mathrm{L}_{0}$ is the capacity of methane gas potential generated in $\mathrm{m}^{3} /$ megagram; $\mathrm{M}_{\mathrm{i}}$ is the mass of waste in the $\mathrm{i}$-year (megagram); and $\mathrm{t}_{\mathrm{i}, \mathrm{j}}$ is the age of the waste mass (in landfill) during the i-year. The total emissions from all sectors are then calculated using equation (10).

\section{Total Emissions $=\sum\left(\right.$ Emission $_{i} x$ GWP value $)(10)$}

where Total Emissions is the total emissions of all types of GHGs $\left(\mathrm{TCO}_{2} \mathrm{eq}\right)$, Emission E $_{\mathrm{i}}$ is $\mathrm{GH}$ emissions from the types of GHGs, GWP is the value of the global warming potential of each type of GHG, and i denotes a type of GHG.

\subsection{Data Analysis and Emission Calculation}

The total GHG is calculated based on the total emissions from activities including landfilling, composting, and LFG utilization, ignoring scavenger activities and the informal sector in reducing the overall GHG emissions. The GWP value is calculated by multiplying the sum of all emissions from these activities by an EF to get the tons of $\mathrm{CO}_{2}$ eq. Furthermore, spatial analysis using ArcGIS ${ }^{\circledR}$ software is performed to show differences in GHG emissions before and after the ITWS optimization plan in the city of Semarang ${ }^{17)}$. The color gradation from dark green to red shows the distribution of emission potential from the smallest to the largest. This spatial analysis does not involve the calculation of emissions from the Jatibarang landfill because the emissions produced are so large that their value is feared to interfere with further analysis. Emission inventory at the Jatibarang landfill is carried out with two scenarios, namely the scenario without and with the use of LFG from closed landfills, sorting, and composting activities.

\section{Results and Discussion}

\subsection{Waste Management in Semarang City}

Semarang city is a metropolitan city where $1,814,110$ people living inside the city. The population density is $4.854 .54 / \mathrm{km} 2$. As per 2019 , this city has 24,800 million USD of GDP in 2019 and 3,790 USD per capita by the World Bank Group. This condition may bring Semarang City as the sixth largest-economic city in Indonesia. The waste management system in Semarang City has not yet fully implemented the $3 \mathrm{R}$. The $3 \mathrm{R}$ activities are mostly performed by the assistance of the informal sector such as waste banks, scavengers, collectors, and flea traders ${ }^{6}$. The amount of waste that enters the Jatibarang landfill is 292,555 tons/year, where the waste is first processed at ITWS, and recovered by the informal sector. Fig. 2 depicts the mass flow of waste in Semarang City. The formal sector only includes waste management from temporary waste storages, ITWSs, waste transportation, and the Jatibarang landfill. However, the government also manages waste from several non-domestic activities such as markets, public facilities, and government offices. The number of temporary waste storages, or "Waste Collection Place" as called in Indonesian tongue, is 208 units, excluding the 22 ITWS units. The difference between TWS and ITWS is the treatment of waste that enters the facility. In ITWS, the incoming waste is first sorted, and then processed according to its type. For instance, organic waste is composted and inorganic waste that still has a sale value is sorted and sold to the informal sector.

However, of the 22 ITWS units, only four were found to manage their waste, namely Diponegoro University (UnDip) ITWS, Pedurungan Lor ITWS, Muktiharjo Kidul ITWS, and Mangkang Wetan ITWS. The generated ITWS waste used as research objects comes from homes, schools, universities, hotels, and hospitals. This causes a difference in the amount of waste that enters the ITWS. UnDip ITWS is the most widely managed and has an amount of 429.44 tons/year, followed by Pedurungan Lor ITWS, Muktiharjo Kidul ITWS, and Mangkang Wetan ITWS, having 58.64, 17.03 , and 13.91 tons/year, respectively. Organic waste (leaves) and plastic are the most widely managed rubbish at the ITWS. This recovery value is still far from the target of the Semarang City government because ITWS can only reduce $0.18 \%$ of the total waste transported to the Jatibarang landfill in 2018.

The Jatibarang Landfill has been operated since 1992. Jatibarang Landfill has one passive and two active zone, where methane from the passive one is extracted to generate electricity. The Jatibarang Landfill is a controlled landfill where every 5-7 days (the height of waste is around $50 \mathrm{~cm}$ ) the waste are closed with local soil layer. The Jatibarang landfill, located in Mijen District, Semarang City, is a final waste processing site. The landfill has an area of 46 hectares and is $\sim 13 \mathrm{~km}$ from downtown Semarang. It consists of four landfill zones, where the gas produced from zone $\mathrm{A}$ is planned to be processed into energy by Garbage Power Plant, which will start operating in 2020. The Garbage Power Plant is expected to produce electricity with a power of 15$20 \mathrm{MW} /$ day. As shown in Fig. 3, the average amount of waste entering the Jatibarang landfill is 801.52 tons/day, with total waste of 292,555 tons in 2018 . The Jatibarang landfill waste is dominated by organic waste at $61.34 \%$ and plastic at $16.34 \%$.

Fig. 4 shows the composition of the landfill waste. Since 2012, organic waste entering the Jatibarang landfill 
has been processed into compost with a capacity of 600 tons/day. However, the compost processing did not go as planned because the sale of compost did not match the operational costs and investment costs; consequently, the composting operation stopped in 2017. At the Jatibarang landfill, $\sim 300$ waste collectors who informally work every day can recover valuable waste. The recycling rate of inorganic waste collected by scavengers is 7.44 tons/day or $0.93 \%$ of the total waste that goes into landfills. Plastic is the most recovered waste $(56 \%)$, followed by paper, $(16 \%)$, metal $(16 \%)$, glass $(11 \%)$, and others $(1 \%)$.

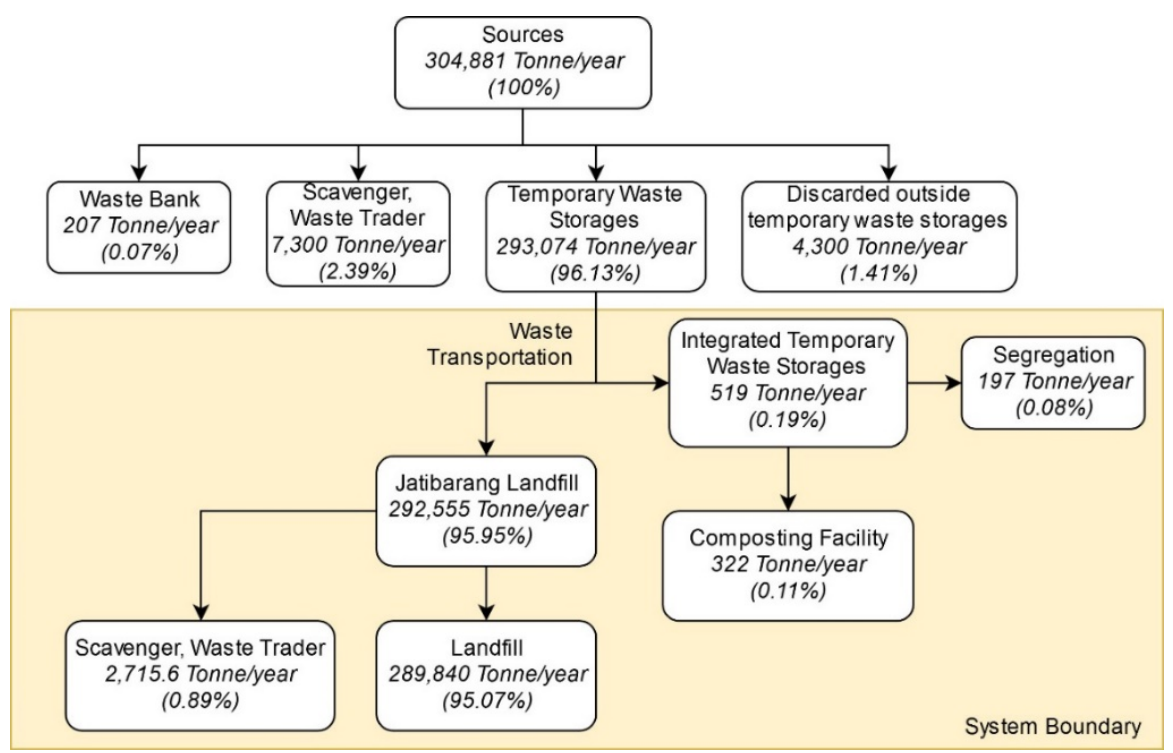

Fig. 2: Waste Management Mass Balance in Semarang City

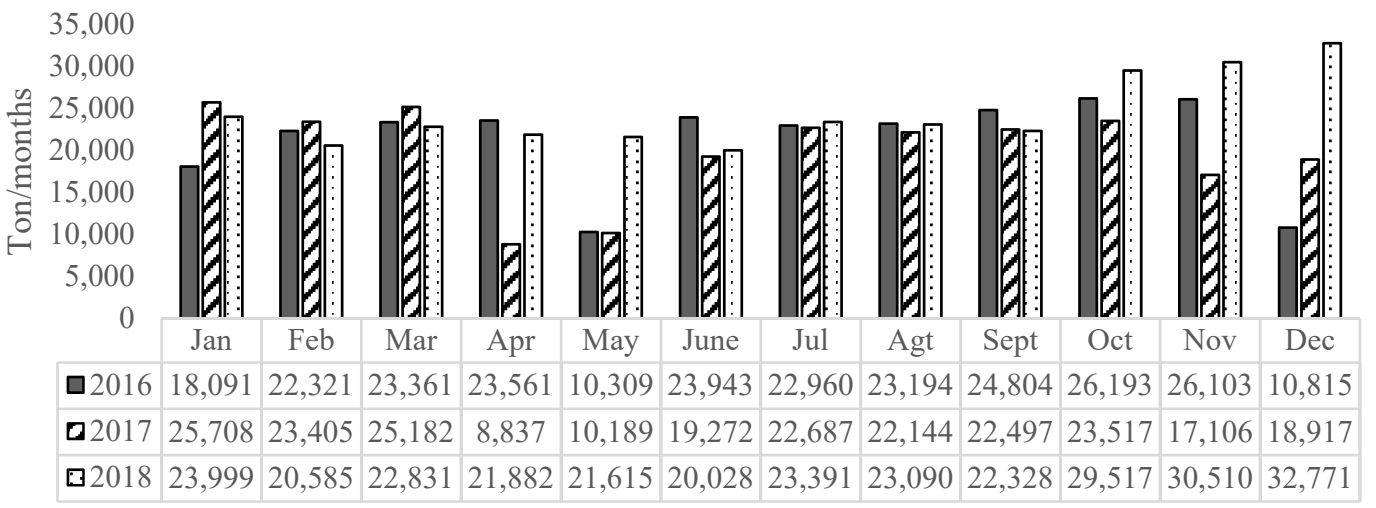

Months

Fig. 3: Jatibarang Landfill Waste Collection in the period of 2016-2018 (in units of ton/months) 


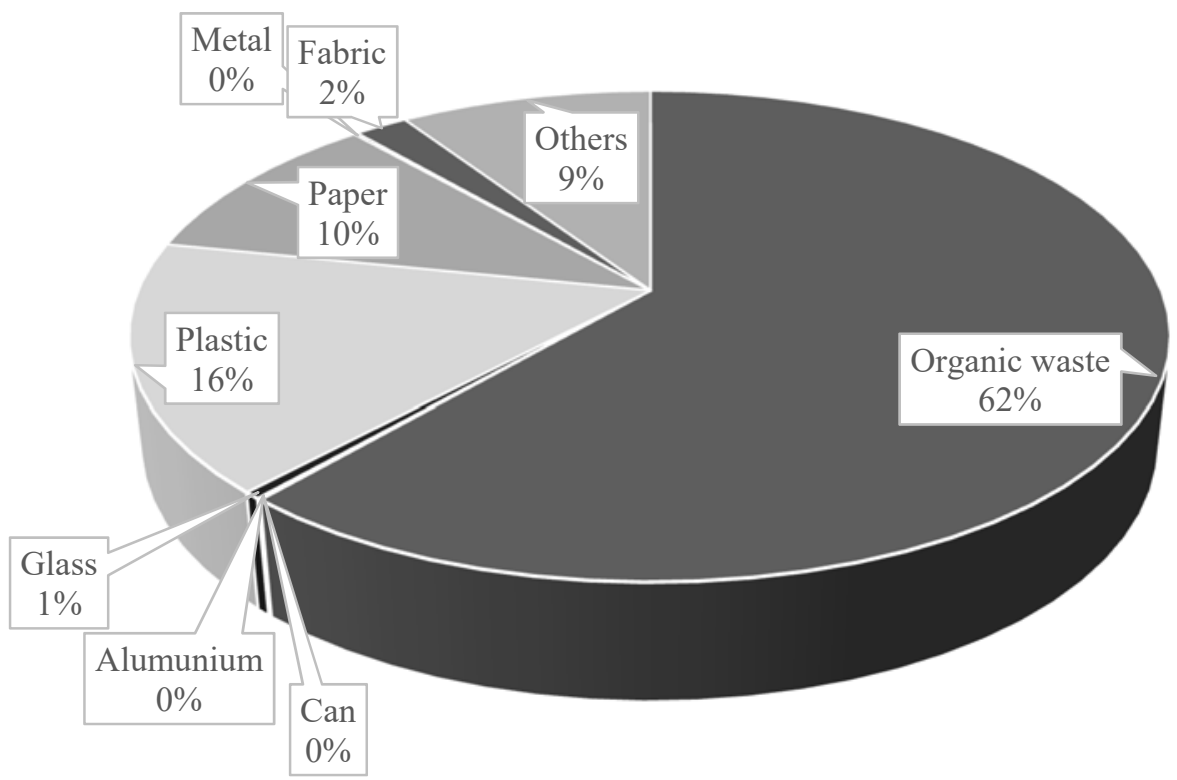

Fig. 4: Jatibarang Landfill Waste Composition

To support waste management in the Jatibarang landfill, infrastructure facilities such as offices, vehicles, and electronic devices are needed. The use of this infrastructure requires energy that comes from fuel oil and electricity. The cost of waste transportation to deliver the waste from temporary waste disposal to landfills is calculated as part of the landfill cost (in terms of the gasoline/diesel cost). Two types of vehicles, which

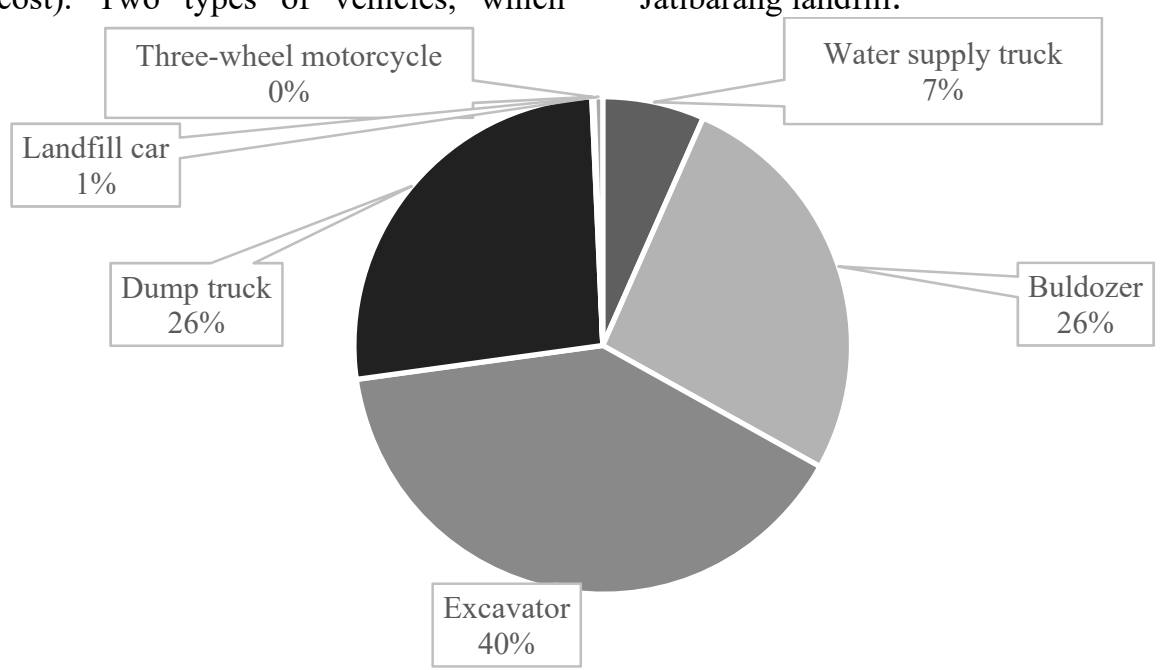

Fig. 5: Percentage of Fuel Needs of Various Vehicles in Landfill

In the landfills, of all vehicles, excavators require the highest amount of fuel oil, with a value of $300 \mathrm{~L} /$ day, while the three-wheeled motorcycles require the least, $1 \mathrm{~L} /$ day. Excavators are used to pick up, organize, and dump waste in the right location. Considering appliances, air conditioners for offices use the most electricity, with an average consumption of $42 \mathrm{kWh}$, while printers use the least, $0.23 \mathrm{kWh}$. Fig. 6 shows the electricity demand for include 170 fleet arm rolls and 41 fleet dump trucks, are still in operation today. Arm-roll trucks require more fuel than dump trucks. The large fleet of arm-roll trucks used for the transportation causes a high demand for fuel: $347.93 \mathrm{~L} /$ day, which is much smaller than that required by dump trucks, i.e., 1,222.87 L/day. Fig. 5 shows the percentage of fuel needed by each vehicle operating in the Jatibarang landfill. each facility. The operational process of the Jatibarang landfill is carried out by 15 people, consisting of heavy equipment operators and office and field officers. Five thousand liters of water is used for toilets, ablutions, washing vehicles, and watering plants. Landfill leachete is treated using a leachate treatment plant consisting of a retention pond, anaerobic pool, facultative pool, maturation pool, and mud dryer. 


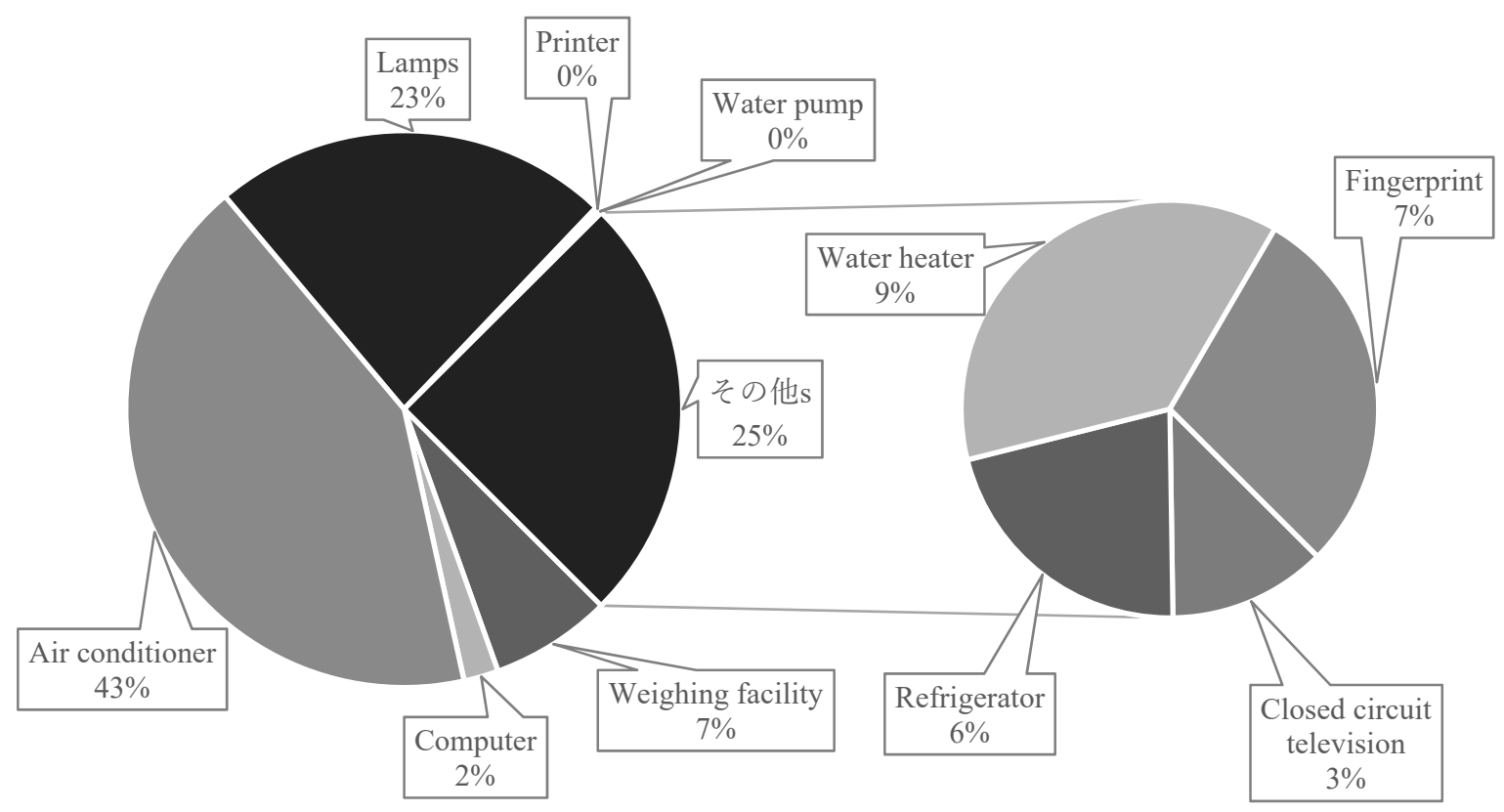

Fig. 6: Percentage of Electricity Needs for Each Equipment in the Jatibarang Landfill

\subsection{Emissions from ITWSs}

The Inventory activity data is linked to a reduction in GHG emissions according to the existing conditions of each activity. The ITWS activities are identical to the sorting, composting, and recycle activities, which are among the efforts to reduce GHG emissions. The South Semarang District has the potential to produce the largest GHG emissions, 12,515 $\mathrm{TCO}_{2}$ eq/year. The district can produce such significant GHG emissions because the Simpang Lima area is the main area of Semarang City; thus, it features activities that support a high level of economy, trade, and education and is therefore visited by many people; these activities and the population are directly proportional to the waste generated. The volume of waste will increase with the increase in population and the increase in technology and socio-economic activities of the community. Some ITWSs such as Mangkang Wetan ITWS do not accept organic waste, so there is no degradation in landfills. The Gunungpati District contributes the least to $\mathrm{GHG}$ emissions, $873 \mathrm{TCO}_{2} \mathrm{eq} / \mathrm{year}$ if waste is not managed, with waste of $6.670 \mathrm{~kg} / \mathrm{day}$, equivalent to 2.684 tons/year. This is because the Gunungpati Subdistrict is dominated by agriculture and animal husbandry activities. In addition, the people who live or visit that sub-districts is relatively few, so only a small amount of waste is generated ${ }^{18)}$. Fig. 7 shows the current map of Semarang City's GHG emission distribution.

\subsection{Emissions from Waste Transportation}

The Semarang City government uses 170 arm-roll fleet and 41 dump trucks for waste transportation. Each vehicle travels an average distance of $17.77 \mathrm{~km}$ and a total distance of $12,566.58 \mathrm{~km}$. The type of fuel used is biodiesel. Each fleet unit requires a total fuel of 1,222.87 1/day for arm-roll and $347.931 /$ months, so that the total diesel consumption per year is $1,507.79$ and the fuel energy consumption is $20.23 \mathrm{TJ} / \mathrm{year}$. Emission estimates calculated using equation (3) for $\mathrm{CO}_{2}, \mathrm{CH}_{4}$, and $\mathrm{N}_{2} \mathrm{O}$ gas from waste transportation activities are $1.52 \times 10^{3}$ $\mathrm{TCO}_{2}$ eq/year.

\subsection{Emissions from Jatibarang Landfill Activity}

Emissions caused by various activities in the landfills are calculated based on the biological processes in the landfills, the use of energy-dependent utilities (indirect emission), and emissions from domestic liquid waste. Details on the emissions from the three activities are explained in the next subsection.

\subsubsection{GHG Emissions from Biological Process}

Waste deposited in landfills can produce large GHG emissions because piled-up organic waste will be degraded anaerobically in order to produce methane gas and carbon dioxide. The methane $\left(\mathrm{CH}_{4}\right)$ gas emissions value calculated using data from the waste entering the landfill (MSWt) is reduced due to the waste taken by scavengers in one year ${ }^{19)}$. The DOC value determines the amount of $\mathrm{CH}_{4}$ gas that can be formed in the degradation process of the organic/carbon components present in the waste composition in the Jatibarang landfill in 2018 (Fig. $3)$. Equation (1) is used to estimate methane emissions from landfill activities. From this equation, the methane emissions produced from waste amount to $1.09 \times 10^{5}$ $\mathrm{TCO}_{2}$ eq/year.

\subsubsection{GHG Emissions in Energy Use}

Greenhouse gas emissions from energy use can be divided into two: emissions from direct and indirect 
energy uses $^{20)}$. Emissions from direct energy usage consist of emissions from the vehicles/heavy equipment operating around landfills. Emissions from indirect energy usage come from the consumption of electrical energy through electrical equipment, including light lamps and other office equipment. Fig. 5 shows the vehicles/heavy equipment available at landfills. The total potential GHG emissions resulting from the use of vehicles in landfills are $7.31 \times 10^{2} \mathrm{TCO}_{2}$ eq/year. Equations (3) and (4) are also used to calculate the amount of $\mathrm{CO}_{2}$ emissions from the use of electronic equipment, by multiplying the secondary $\mathrm{EF}$ by the amount of electricity consumed in the Jatibarang landfill every month. From the calculations, the value of $\mathrm{CO}_{2}$ emissions from total electricity usage is $5.84 \times 10^{-2} \quad \mathrm{TCO}_{2}$ eq/year. Thus, the total emissions generated from energy needs is $7.31 \times 10^{2} \mathrm{TCO}_{2} \mathrm{eq} /$ year.

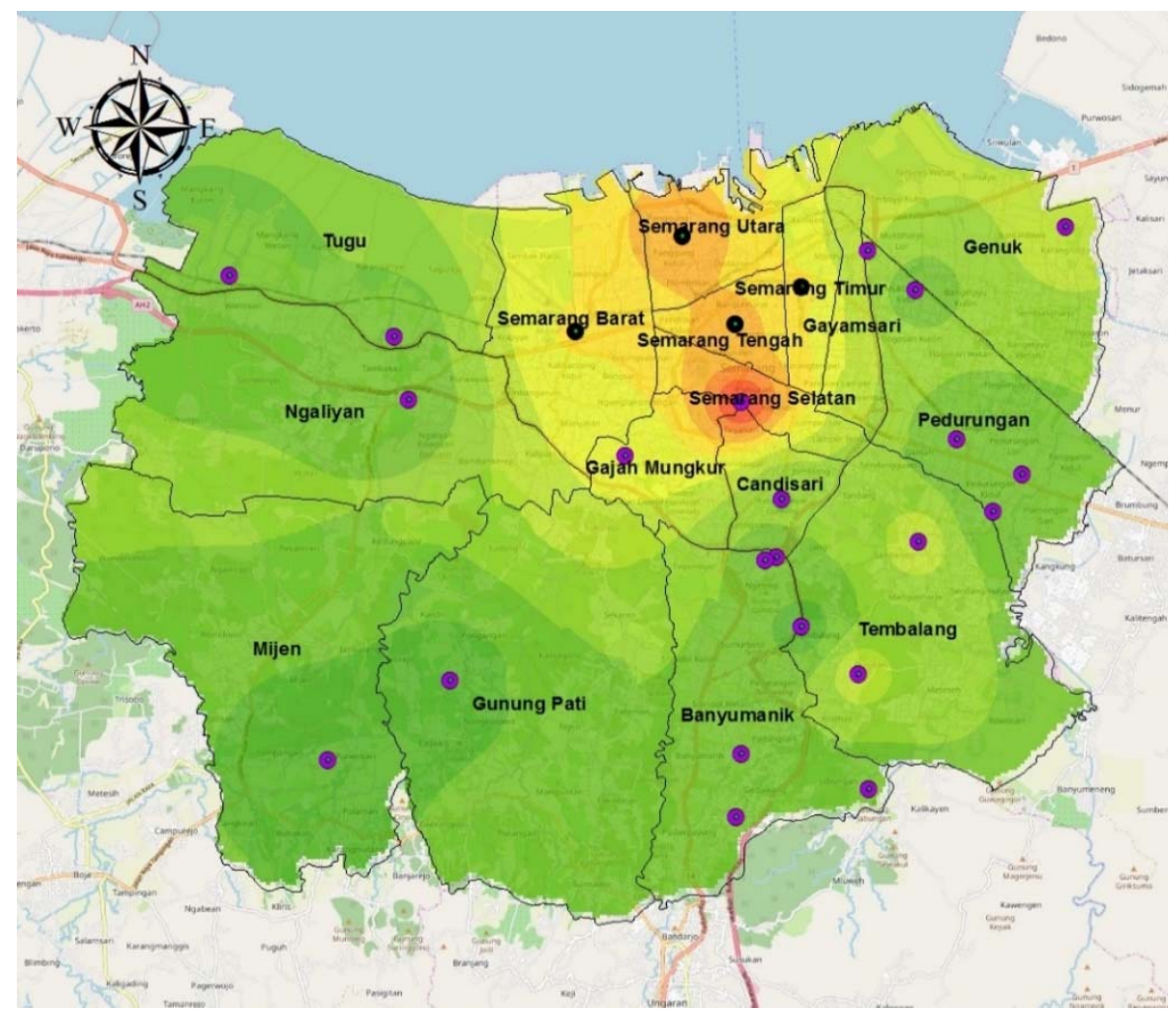

Fig. 7: Distribution of Existing Semarang City GHG Emissions

\subsubsection{GHG Emissions from Liquid Waste}

The large population in office activities that consume clean water is used as a basis to analyze emissions resulting from domestic wastewater production. The calculation of emissions from domestic waste is distinguished based on the production of gray water and black water. The generated wastewater is assumed to be $50 \%-80 \%$ of the total amount of used clean water, where $75 \%$ of the wastewater is considered gray water. The average water used for office activities is assumed to be 333.3 L/person/day. An important principle in determining $\mathrm{CH}_{4}$ production is to determine the amount of organic material decomposed in wastewater or the TOW. This data is obtained from the selection of activity data, where the parameters used are a function of the total population (wastewater producer) and BOD as general parameters produced by each person $(\mathrm{kg} \mathrm{BOD} / \mathrm{year})^{21)}$. The number of BOD per capita in Indonesia is $13 \mathrm{gr}$ $\mathrm{BOD} /$ person/day for black water and $27 \mathrm{gr}$ BOD/person/day for gray water. From equation (7), the amount of emissions from domestic waste management is estimated as $5.96 \times 10^{-1} \mathrm{TCO}_{2} \mathrm{eq} /$ year.
Methane emissions are influenced by the TOW, which is a major factor in determining the potential of $\mathrm{CH}_{4}$ occurrence in wastewater. The amount of $\mathrm{CH}_{4}$ emissions from liquid waste is determined using per capita BOD parameters and the population that produces wastewater. The magnitude of $\mathrm{CH}_{4}$ emissions is directly proportional to the TOW. The higher the TOW, the higher the $\mathrm{CH}_{4}$ produced. The presence of $\mathrm{N}_{2} \mathrm{O}$ is influenced by the breakdown of nitrogen components in wastewater in the form of urea, nitrates, and proteins. In this study, water management in the form of effluent gray water is discharged into the environment through open channels. Greenhouse gas emissions are reviewed through indirect $\mathrm{N}_{2} \mathrm{O}$ emissions, which are emissions during effluent disposal. The amount of $\mathrm{N}_{2} \mathrm{O}$ emissions can be obtained by calculating the total nitrogen in wastewater $\left(\mathrm{N}_{\text {effluent }}\right)$. Here, $\mathrm{N}_{\text {effluent }}$ consists of several data such as population, protein consumption per capita in a year, nitrogen fraction, unconsumed protein factor, and also the factor of protein removed into the drain ${ }^{22)}$.

This research was conducted based on calculations with the modification of the 2006 IPCC formula through a tier- 
2 approach, involving the use of IPCC default values and country-specific data. In calculating the projections, the least-squares method is known to yield the smallest standard deviation. Thus, the protein consumption per capita of $22.55 \mathrm{~kg} /$ person/year refers to the results of projections obtained using the least-squares method. Wastewater containing protein has a relationship with the amount of total nitrogen in the effluent; therefore, it is necessary to know in advance the total nitrogen in the wastewater before obtaining the amount of $\mathrm{N}_{2} \mathrm{O}$ emissions. From the conducted calculations, the potential $\mathrm{N}_{2} \mathrm{O}$ emission that occurs is $0.595 \mathrm{~kg} \mathrm{~N}_{2} \mathrm{O}$ /year, equivalent to $0.16 \mathrm{TCO}_{2}$ eq/year. Nitrous oxide emissions affect the nitrogen amount in water, where the total nitrogen in water is directly proportional to the population. The higher the population, the higher the total nitrogen in water, resulting in greater $\mathrm{N}_{2} \mathrm{O}$ emissions. The total $\mathrm{GHG}$ emissions amount from domestic wastewater is $7.54 \times 10^{-1} \mathrm{TCO}_{2} \mathrm{eq} /$ year.

\subsection{Optimization Scenario}

The optimization scenario involves improving the waste management at the Jatibarang landfill by implementing the $3 \mathrm{R}$ principles on site. In the landfills, there are plans for LFG recovery activities in closed zones. The potential LFG is calculated using the LandGEM v3.02 equation. In addition, composting activities are carried out at landfills to handle organic residues that cannot be treated at the ITWS. The potential value of GHG emissions is the basis of the goal of the optimization scenario. The city of Semarang itself wants to control the rate of climate change with a target of reducing GHG emissions by $4 \%$ from the initial year of calculation in 2020. The existence of the waste-to-energy ( $\mathrm{WtE}$ ) power plant in the Jatibarang landfill is part of the government program to realize the Clean Indonesia Movement. The WtE utilizes methane gas produced from organic fraction in landfills ${ }^{9)}$. Microbial activity in landfills produces $\mathrm{CH}_{4}$ and $\mathrm{CO}_{2}$ gases (in the early stages-aerobic processes) and methane gas (anaerobic process) ${ }^{2}$. The LFG collection system usually consists of several wells in pipes that are installed laterally and connected by a central vacuum pump. In addition, a gas extraction system with a decentralized pump is also present ${ }^{14), 17)}$. Waste-to-energy power plants use methane gas. To estimate the production of methane gas from the amount of waste, the LandGEM method is used as a calculation model. LandGEM is an automatic estimation tool with a Microsoft Excel interface that can be used to estimate emission levels for total LFG, methane, carbon dioxide, non-methane organic compounds, and individual air pollutants from municipal solid waste landfills ${ }^{15}$.

This method is easy to use for countries that have limited data related to domestic waste in landfills. The LandGEM model assumes that waste is considered homogeneous, $\mathrm{k}$ and $\mathrm{L}_{0}$ values are constant. In this study, the values of $\mathrm{k}, \mathrm{L}_{0}$, and NMOC (non-methane organic compounds) concentration were determined with a $\mathrm{k}$ value of $0.05 /$ year, $\mathrm{L}_{0}$ of $170 \mathrm{~m}^{3} /$ megagram, and NMOC concentration of 4,000 $\mathrm{ppm}_{\mathrm{v}}$ hexane, with methane gas volume of $50 \%$ of the total gas volume generated at the landfil ${ }^{2), 55,23)}$. Due to the limited data on waste generation entering the Jatibarang landfill from its establishment in 1992 to its closure in 2017 for zone A, the number of waste generation entering the landfill is calculated by multiplying the population of Semarang City in the study year with a per capita generation of $0.4 \mathrm{~kg} /$ person/day, then multiplied by the percentage of the Jatibarang landfill services from the start of operation. From Fig. 8, it is known that the potential peak value, i.e., $1.32 \times 10^{4}$ $\mathrm{TCH}_{4} /$ year and $3.63 \times 10^{4} \mathrm{TCO}_{2} /$ year, equivalent to $4.07 \times 10^{5} \mathrm{TCO}_{2} \mathrm{eq} /$ year, corresponds to a point after the year of landfill closure, i.e., 2018. The potential value from 1993 to 2018 constantly increases due to the addition of wastes in landfills. The LFG consisting of methane and carbon dioxide increases every year up to 2019 because of the constant anaerobic process occurring in the piled-up waste at the landfill. From 2019 onward, the potential LFG is predicted to decline, and in 2133 , it is predicted to run out if it is not utilized. In the inventory year, 2019, the production of a potential LFG of $1.26 \times 10^{4} \mathrm{TCH}_{4} /$ year and $3.46 \times 10^{4} \mathrm{TCO}_{2}$ eq/year, or equivalent to $3.87 \times 10^{4}$ $\mathrm{TCO}_{2}$ eq/year, is estimated. If in 2020 LFG starts to be extracted and recovered, the potential LFG that can be utilized from the closed landfill until 2133 is $6.86 \times 10^{6}$ $\mathrm{TCO}_{2}$ eq/year.

Composting is an aerobic process involving the conversion of DOC components in waste to carbon dioxide $\left(\mathrm{CO}_{2}\right)^{24)}$. Methane is formed in the compost anaerobic session, but it is oxidized to a large degree in the compost aerobic session. The estimated range of $\mathrm{CH}_{4}$ released into the atmosphere is less than $1 \%$ to several percent of the initial carbon content in the material. Nitrous oxide is also produced in the composting process $^{4), 22}$ The estimated emission ranges from $<0.5 \%$ to $5 \%$ of the initial nitrogen content of the material. The private sector around the landfill zone composts organic waste in the Jatibarang landfill. In 2018, the private sector working on composting activities was closed for various reasons. In fact, composting itself has a significant share in reducing the amount of wastes entering landfills. Carbon dioxide emissions resulting from composting are a result of aerobic processes, due to the conversion of the DOC components in wastes to $\mathrm{CO}_{2}$. Methane emissions are affected by the dumping of organic waste at the final processing site and open waste burning ${ }^{8)}$. Nitrous oxide emissions can be generated from the processes of soil fertilization, land use, biomass burning, fossil fuel usage, and composting ${ }^{25}$. From the conducted calculation, the total emission from composting activities is $4.19 \times 10^{4}$ $\mathrm{TCO}_{2} \mathrm{eq} /$ year, assuming the generation of waste processed as compost is $600 \mathrm{~T} / \mathrm{d}$.

In the optimization scheme, the number of waste entering the active landfill zone has decreased due to 
informal sector/scavenger activities and composting activities carried out by profit organizations. Scavengers are assumed capable of taking $2.72 \times 10^{3} \mathrm{~T} / \mathrm{y}$ nonorganic waste, and the amount of waste with the potential for composting is $2.19 \times 10^{5} \mathrm{~T} / \mathrm{y}$. This shows a severe waste reduction due to these activities. As a result, the potential for methane emissions resulting from biological processes in landfills is reduced to $1.10 \times 10^{3} \mathrm{TCH}_{4} /$ year, equivalent to $2.76 \times 10^{4} \mathrm{TCO}_{2}$ eq/year. This value is smaller than the emission value in the existing condition, which is $1.09 \times 10^{5} \mathrm{TCO}_{2}$ eq/year. Biogas that is formed is also recovered to be used for electricity/heat generation (steam) or burned to avoid the $\mathrm{CH}_{4}$ release (because the gas is a GHG and also for safety reasons as the gas is flammable $)^{26)}$. Thus, the amount of $\mathrm{CH}_{4}$ gas emissions is the total $\mathrm{CH}_{4}$ gas that is recovered/burned.

The utilization of composting process is showing a good contribution on the reduction of GHG emission. Yedia and Sindhu (2016), stated that anaerobic composting through anaerobic digestion can reduce 0.79 times GHG emission than open dumping operation ${ }^{27)}$. In other hand, anaerobic digestion has higher emission than aerobic composting process ${ }^{28}$. Composting which is integrated with in-source recycling is proven to give a significant reduction of GHG emission (around 47\%). This value is empowering the finding of this research that is composting could reduce the amount of the total gas produced each year. In-source recycling may endorsed so the emission of landfill system could be reduced more ${ }^{29)}$.

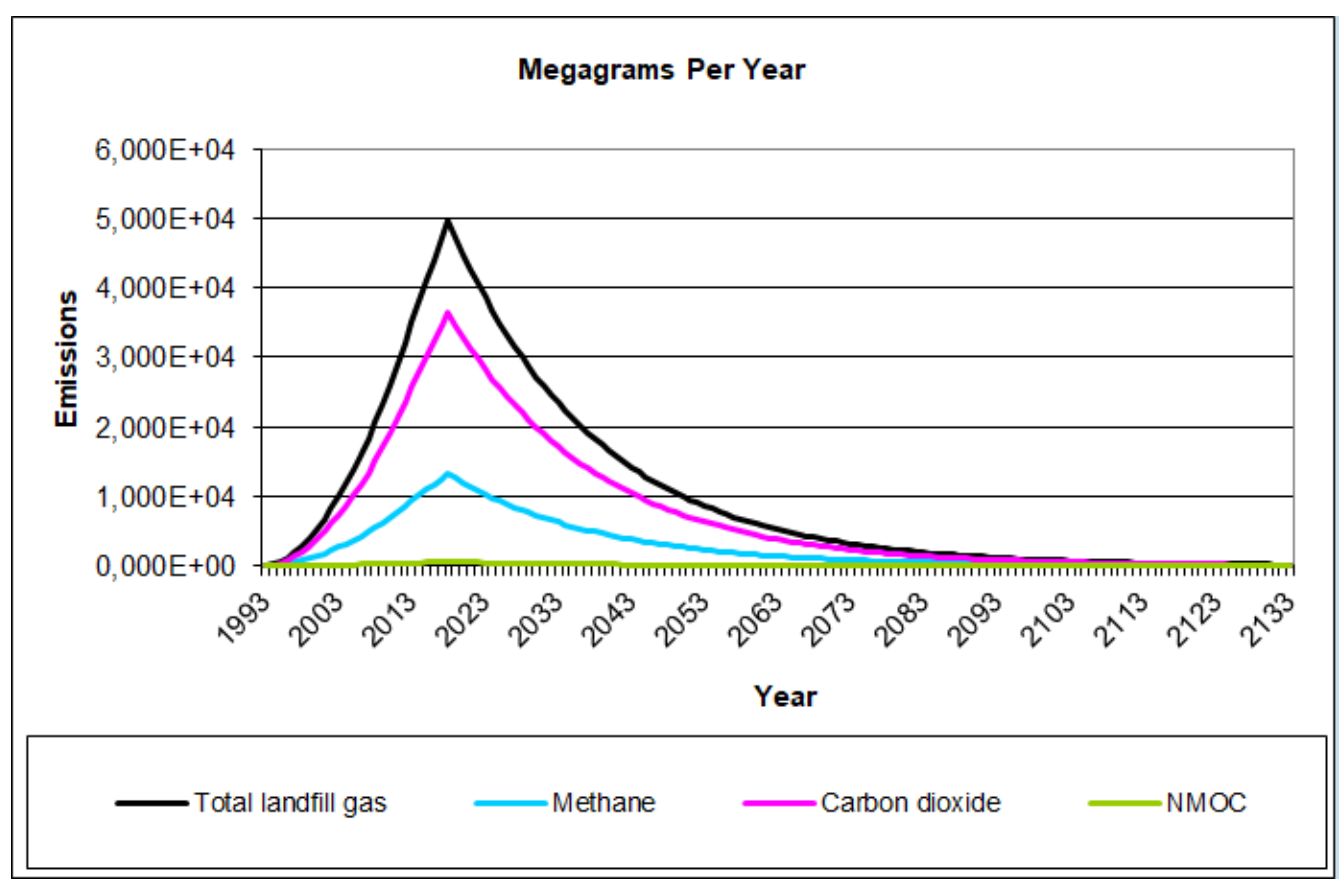

Fig. 8: Graph of potential LFG generated per year in zones that have been closed

Table 2. Summary of Waste Management Emissions

\begin{tabular}{|l|l|l|}
\hline \multirow{2}{*}{ Activity Details } & Emissions (TCO2eq/year) & \\
\cline { 2 - 3 } & Current Scenario & Optimization Scenario \\
\hline Transportation & $1.52 \times 10^{3}$ & $1.52 \times 10^{3}$ \\
\hline Active landfill site & $1.09 \times 10^{5}$ & $2.76 \times 10^{4}$ \\
\hline Closed landfill site & $3.87 \times 10^{4}$ & $3.87 \times 10^{4}$ \\
\hline Energy use & $7.31 \times 10^{2}$ & $7.31 \times 10^{2}$ \\
\hline Domestic wastewater & $7.54 \times 10^{-1}$ & $7.54 \times 10^{-1}$ \\
\hline Composting Process & - & $4.19 \times 10^{4}$ \\
\hline Total emissions & $\mathbf{1 . 6 5} \times \mathbf{1 0}^{\mathbf{5}}$ & $\mathbf{7 . 1 7} \times \mathbf{1 0}^{\mathbf{4}}$ \\
\hline Utilized & - & $\mathbf{3 . 8 7} \times \mathbf{1 0}^{\mathbf{4}}$ \\
\hline
\end{tabular}

\section{Conclusion}

The total potential GHG emissions generated by the city of Semarang in the existing condition if all the waste is piled up in landfills is $1.65 \times 10^{5} \mathrm{TCO}_{2}$ eq/year, so that the emissions produced by each person at this time amount to $167,5 \mathrm{gCO}_{2}$ eq/person/day. The amount of GHG emissions generated in the optimization scenario is $7.17 \times 10^{4} \mathrm{TCO}_{2} \mathrm{eq} /$ year. The South Semarang District has the potential to produce the highest GHG, which accounts for around $13 \%$ of the total existing GHG emissions. From the field of waste management, emissions can be reduced 
by developing alternative and renewable energy sources such as LFG utilization and the reactivation of composting activities before depositing wastes in landfills. From the conducted calculations, if LFG can be used for energy generation in 2020, then the local government has the potential to reduce energy wastage and LFG disposal into the environment by $3.84 \times 10^{4} \mathrm{TCO}_{2} \mathrm{eq} /$ year.

\section{Acknowledgement}

This research was funded through the UNDIP Faculty of Engineering RKAT Funding Source, Fiscal Year 2019 with the contract number 0208/FTE/SPM-KS/JUL/2019.

\section{References}

1) Y.C. Chan, R.K. Sinha, W. Wang, "Emission of greenhouse gases from home aerobic composting, anaerobic digestion and vermicomposting of household wastes in Brisbane (Australia)," Waste Manage. $\quad$ Res., 29(5) 540-548. https://doi.org/10.1177/0734242X10375587

2) N.A. Chusna, M. Maryono, "Preliminary evaluation of method to monitor landfills resilience against methane emission", E3S Web of Conferences, 1-5 (2018). doi:10.1051/e3sconf/20183105006

3) A. Wahid, D.R. Mustafida, Y.A. Husnil, "Exergy analysis of coal-fired power plants in ultra supercritical technology versus integrated gasification combined cycle," Evergreen, 7(1) 32-42 (2020). https://doi.org/10.5109/2740939

4) M.B. Jensen, J.Møller, J. Mønster, C. Scheutz, "Quantification of greenhouse gas emissions from a biological waste treatment facility," Waste Manage., 67 375-384

(2017). doi:10.1016/j.wasman.2017.05.033

5) E. Chalvatzaki, M. Lazaridis,. "Estimation of greenhouse gas emissions from landfills: Application to the Akrotiri landfill site (Chania, Greece)," Glob. Nest J., 12 108-116 (2010).

6) E. Friedrich, C. Trois, "Quantification of greenhouse gas emissions from waste management processes for municipalities - A comparative review focusing on Africa," Waste Manag., 31 1585-1596 (2011). doi:10.1016/j.wasman.2011.02.028

7) M.T. Kibria, M.A. Islam, B.B. Saha, T. Nakagawa, S. Mizuno, "Assessment of environmental impact for air-conditioning systems in japan using HFC based refrigerants," Evergreen, 6(3) 246-253 (2019). http://hdl.handle.net/2324/2349301

8) W.A. Qazi, M.-H. Azam, U.A. Mehmood, G.A. AlMufragi, N.-A. Alrawahi, M.F.M. Abushammala, "Quantification of methane emissions from solid waste in oman using IPCC default methodology," Int. J. Environ. Ecol. Eng., 10 173-177 (2016). doi:10.1017/CBO9781107415324.004

9) E. Damanhuri, W. Handoko, T. Padmi, Municipal Solid Waste Management in Indonesia, in: Pariatamby, A., Tanaka, M. (Eds.)," MSW Manag. in
Asia and the Pacific Islands. Springer, Singapore, 139-155 (2014). doi:10.1007/978-981-4451-73-4_8

10) Z. Lou, B. Cai, N. Zhu, Y. Zhao, Y. Geng, B. Yu, W. Chen, "Greenhouse gas emission inventories from waste sector in China during 1949-2013 and its mitigation potential," J. Clean. Prod., 157 118-124 (2017). https://doi.org/10.1016/j.jclepro.2017.04.135

11) M.J.S. Zuberi, S.F. Ali, "Greenhouse effect reduction by recovering energy from waste landfills in Pakistan," Renew. Sust. Energ. Rev., 44 117-131 (2015). https://doi.org/10.1016/j.rser.2014.12.028

12) S. Raharjo, T. Matsumoto, T. Ihsan, I. Rachman, L. Gustin, "Community-based solid waste bank program for municipal solid waste management improvement in Indonesia: a case study of Padang city, “ Evergreen, 19 201-212 (2017). https://doi.org/10.1007/s10163-015-0401-z

13) H. Gima, T. Yoshitake, "A comparative study of energy security in Okinawa Prefecture and the State of Hawaii," Evergreen, 3(2) 36-44. https://doi.org/10.5109/1800870

14) E.A. Mohareb, H.L. MacLean, C.A. Kennedy, "Greenhouse gas emissions from waste managementAssessment of quantification methods.," J. Air Waste Manag. Assoc., $61 \quad 480-493 \quad$ (2011). doi:10.3155/1047-3289.61.5.480

15) B. Dimishkovska, A. Berisha, K. Lisichkov, "Estimation of methane emissions from Mirash municipal solid waste sanitary landfill, differences between IPPC 2006 and LandGEM method," J. Ecol. Eng., $\quad 20 \quad 35-41 \quad$ (2019). doi:10.12911/22998993/105332

16) P. Ghosh, G. Shah, R. Chandra, S. Sahota, H. Kumar, V.K. Vijay, I.S. Thakur, "Assessment of methane emissions and energy recovery potential from the municipal solid waste landfills of Delhi, India," Bioresour. Technol., 272 611-615 (2019). doi:10.1016/j.biortech.2018.10.069

17) C. Zhang, Y. Guo, X. Wang, S.Chen, "Temporal and spatial variation of greenhouse gas emissions from a limited-controlled landfill site," Environ. Int., 127 387-394 (2019). doi:10.1016/j.envint.2019.03.052

18) C. Zhou, D. Jiang, Z. Zhao, "Quantification of greenhouse gas emissions from the predisposal stage of municipal solid waste management," Environ. Sci. Technol., $\quad 51 \quad 320-327 \quad$ (2017). doi:10.1021/acs.est.6b05180

19) J. O’Dwyer, D. Walshe, K.A. Byrne, "Wood waste decomposition in landfills: An assessment of current knowledge and implications for emissions reporting," Waste Manage., $73 \quad 181-188 \quad$ (2018). doi:10.1016/j.wasman.2017.12.002

20) H. Akamine, M. Mitsuhara, M. Nishida, "Developments of coal-fired power plants: Microscopy study of Fe-Ni based heat-resistant alloy for efficiency improvement," Evergreen, 3(2) 45-53 (2016). https://doi.org/10.5109/1800871 
21) T.G. Poulsen, J.A. Hansen," Assessing the impacts of changes in treatment technology on energy and greenhouse gas balances for organic waste and wastewater treatment using historical data," Waste Manage. Res., 27(9) 861-870. https://doi.org/10.1177/0734242X09349557

22) N.T. Hoa, Y. Matsuoka, "The analysis of greenhouse gas emissions/reductions in waste sector in Vietnam. Mitig," Adapt. Strateg. Glob. Chang., 22, 427-446 (2017) . doi:10.1007/s11027-015-9679-3

23) A. Alexander, C. Burklin, A. Singleton, "Landfill Gas Emissions Model (LandGEM) Version 3.02 User's Guide," (2005)

24) H.Y. Hwang, S.H. Kim, J. Shim, S.J. Park, "Composting process and gas emissions during foodwaste composting under the effect of different additives," Sustainability, 127811 (2020). https://doi.org/10.3390/su1218781

25) J.G.J. Olivier, J.A.Van Aardenne, F.J. Dentener, V. Pagliari, L.N. Ganzeveld, J.A.H.W. Peters, "Recent trends in global greenhouse gas emissions:regional trends 1970-2000 and spatial distributionof key sources in 2000," Environ. Sci., 2 81-99 (2005). doi:10.1080/15693430500400345

26) U. Lee, J. Han, M. Wang, "Evaluation of landfill gas emissions from municipal solid waste landfills for the life-cycle analysis of waste-to-energy pathways," $J$. Clean. Prod., $166 \quad 335-342 \quad$ (2017). doi:10.1016/j.jclepro.2017.08.016

27) S. Yedia, N. Sindhu, "Assessment of alternative disposal methods to reduce greenhouse gas emissions from municipal solid waste in India," Waste Manag. Res., $34 \quad 553-563 \quad$ (2016). Doi: $10.1177 / 0734242 X 16643176$

28) J.A. Moult, S.R. Allan, C.N. Hewitt, M. Berners-Lee, "Greenhouse gas emissions of food waste disposal options for UK retailers," Food Policy, 77 50-58 (2018). doi: 10.1016/j.foodpol.2018.04.003

29) S. Babel, X. Vilaysouk, "Greenhouse gas emissions from municipal solid waste management in Vientiane, Lao PDR," Waste Manag. Res., 34(1) 30-37 (2015). doi: $10.1177 / 0734242 X 15615425$ 